\title{
Penaeus notialis (Pink Shrimps): Length-Weight Relationships and Condition Factor in Lagos Lagoon, South West, Nigeria
}

\author{
Lawal-Are A.O., Akinjogunla V. F.* \\ Department of Marine Sciences, Faculty of Science, University of Lagos, Akoka, Lagos State
}

\begin{abstract}
The Length-Weight Relationship (LWR) and condition factors (K) of 600 pink shrimps (Penaeus notialis) obtained from Makoko Jetty off Lagos Lagoon between January and June, 2009 were studied. The carapace length of Penaeus notialis ranged from $2.0 \mathrm{~cm}$ to $12.1 \mathrm{~cm}$ and $1.4 \mathrm{~cm}$ to $11.5 \mathrm{~cm}$ in females and males, respectively. The slope or regression coefficient (b) obtained for Carapace Length-Total Length Relationship ranged from 0.0001 in combined sexes to 1.3889 in males while the intercept (a) varied between 0.4754 and 0.8416 . The value for ' $b$ ' and ' $a$ ' in Carapace Weight-Total Weight Relationship of P. notialis was highest in females and males, respectively. In the Carapace Length-Total Weight Relationship, the males' P. notialis showed the highest regression constant (a) of 1.2345 and regression coefficient (b) of 0.8059 . Generally, the values of the regression coefficient were lower than 3.0 for males, females and combined sexes, reflecting a negative allometric growth of the P. notialis. The results showed that there were differences in the condition factors for males and females. The lowest ' $\mathrm{K}$ ' value for the female species was found in size group 7.5-8.4, while the highest ' $\mathrm{K}$ ' value was obtained in size group 6.5-7.4. The male species had $\mathrm{K}$ values ranging between 0.18 and 80.29 . There was variation in condition values for the combined sexes as the size group $1.0-1.4$ had the highest $\mathrm{K}$-value and size group $6.5-7.4$ had the lowest K-value.
\end{abstract}

Keywords Penaeus notialis, shrimps, Lagoon, Length, Weight, Carapace

\section{Introduction}

Pink shrimp, Penaeus notialis belongs to the family Penaeidae. It can be distinguished from other families of shrimp due to their antennae, which are longer than their body lengths (Amos and Amos, 1997). The integument is thin, translucent and the overall body colour is highly variable, but generally gray, bluish or red-brown. The carapace has a medial carina that extends nearly to the posterior end of carapace and is bordered by a broad, rounded groove on either side. Ventrally, the rostrum may have 1- 3 teeth (Carvajal and Nebot, 1998). The abdomen has $4-6$ carinate segments, with the carina of the sixth segment ending in a spine. A dark, distinct spot on the pleural junction between the 3rd and 4th abdominal segments can be used to distinguish this species from other members of the genus. The tail is edged with blue coloration, and the telson has a deep medial groove (Griffith and Wigglesworth, 1993; Amos and Amos, 1997). Pink shrimps are typically found in both es tuaries and inhabiting the inner littoral zone along coasts.

* Corresponding author:

Vicakin@yahoo.com (Akinjogunla V.F.)

Published online at http://journal.sapub.org/scit

Copyright (C) 2012 Scientific \& Academic Publishing. All Rights Reserved
They live on muddy bottom by day and migrate upward by night from the region (Ansa, 2005). The youngest size classes of Penaeus notialis seek out shallow, less saline areas in estuarine nursery habitats and are often found abundantly in sea-grasses, with older shrimp more likely to utilize patchily distributed sea-grass areas (Adetayo and Kusemiju, 1994;Sanchez, 1997). Penaeus notialis is sexually dimorphic, with large males attaining a length of $169 \mathrm{~mm}$ and large females reaching over $280 \mathrm{~mm}$. (Jalihal et. al. 1993; Adetayo and Kusemiju, 1994). The adult pink shrimp stock off Lagos Coast has been reported to be replenished by the juveniles and sub-adult from the adjacent Lagos Lagoon (Adetayo and Kusemiju 1994). It therefore follows that the population of the pink shrimp at sea and catches available off the Lagos coast depend primarily on the annual recruitment from the Lagos Lagoon. The distribution of the adult pink shrimp off shore at depths of $15-25$ fathoms $(27-46 \mathrm{~m})$ has been observed by Adetayo and Kusemiju (1994). Due to the economic importance of penaeid shrimps (Pink shrimps) worldwide, particularly in aquaculture, a great effort to understand the growth biology of Penaeus spp. has been made in recent years. Growth depends on sex, stage and environmental factors such as temperature (Wyban et al., 1995; Miao and Tu, 1996; Ye et al., 2003; Lopez-Martinez et al., 2003), salinity (Lemos et al., 2001), quantity and quality 
(Dall et al., 1990), lunar cycles (Griffith and Wigglesworth, 1993) and water. Condition factor has been used as an index of growth and feeding intensity (Fagade, 1979). Condition factor decrease with increase in length (Fagade, 1979); and also influences the reproductive cycle in fish (Welcome, 1979). Length-weight regressions have been used frequently to estimate weight from length because direct weight measurements can be time-consuming in the field (Sinovcic et al., 2004). One of the most commonly used analyses of fisheries data is length-weight relationship (Mendes et al., 2004). Although various studies have been carried out regarding Pink shrimps, there is a dearth and paucity of information on Length-weight relationships of this shellfish from this part of the Country. It is on the basis of this that this study was embarked on aiming at providing useful information on the length-weight relationship (LWR) and condition factors of Pink shrimps (Penaeus notialis) caught in Lagos Lagoon, Nigeria.

\section{Materials and Methods}

\section{Description Of Study Area}

The Lagos Lagoon (Figure 1) which lies between longitudes $3020^{\prime}$ ' and $3040^{\prime} \mathrm{E}$ and latitudes $6015^{\prime}$ and $6040^{\prime}$ has an area of $208 \mathrm{~km} 2$ and is the largest of the Lagoon systems of the West African sub-region. It is the largest of the nine coastal lagoons of South-western Nigeria. Others are Yewa, Badagry, Iyagbe, Ologe, Kuramo, Epe, Lekki and Main Lagoons). Characteristically, Lagos Lagoon has a seasonal fluctuation in salinity and high brackish water during the dry season (From December to May), while freshwater condition exists in the rainy season (June - November) (Kusemiju, 1975; Ugwumba and Kusemiju, 1992; Solarin, 1998; Lawal-Are, 2006). Lagos Lagoon receives freshwater from Lekki Lagoon via Epe Lagoon in the North-east, and discharges from Majidun, Agboyi and Ogudu creeks as well as Ogun River in the North-west (Soyinka, 2008; Lawal-Are et al., 2010, Lawal-Are and Nwankwo, 2011).

\section{Catching Of Pink Shrimps}

Artisanal Shrimpers (Fishermen) mainly exploit the fisheries. The Shrimpers use wooden boats or canoes with size ranging from 5 to $12 \mathrm{~m}$ long. The canoes / boats are either paddled or powered by small outboard engines, and manned by an average of two men. From these boats / canoes, the Shrimpers cast their shrimping nets.

\section{Collection of Specimens}

Six hundred (600) samples of Pink shrimps (Penaeus notialis) were collected on monthly basis between the months of January and June 2009, from the artisinal fishermen from Makoko Jetty area of Lagos Lagoon who carry out mainly P. notialis fishery. The specimens (P. notialis) were immediately preserved using iced packed cooler and immediately transferred to the Department of Marine Sciences, University of Lagos and kept in the Freezer at $-4 \mathrm{oC}$ for further biological investigations.

\section{Growth Pattern (Length and Weight)}

The Carapace Length (CL), Total Length (TL), Rostral Length (RL) and Telson Length (TL) of the P. notialis were measured in Centimetres $(\mathrm{cm})$ using the graduated measuring ruler, while the Total Weight (TW) and Carapace Weight (CW) of the P. notialis were measured using a Sartorius top loading balance (Model 1100). Total Length measured to the nearest centimetre was obtained by stretching out the curved shrimp and taking lengths from the telson to the base of the eyestalk. The Telson Length was measured from the posterior end of the carapace to the base of the telson while the Carapace Length obtained by cutting off the cephalothoraxes and taking measurements from the posterior end of the carapace to the base of the eyestalk was measured to the nearest centimetre. The Total Weights of whole specimens were made using a Top Beam Balance after excess water had been removed from the shrimp and the measurement was to the nearest gram. The length- weight relationship (LWR) was calculated using the below equation as given by Sparre and Venema (1992).

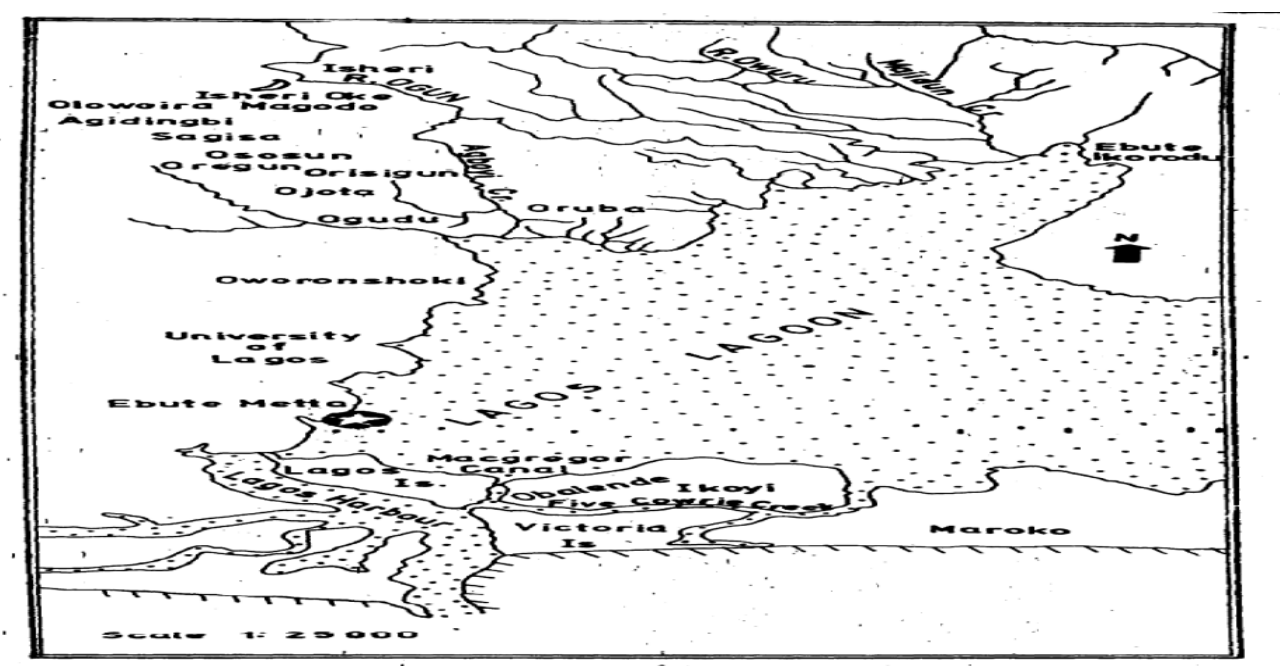

Figure 1. Map showing Lagos Lagoon and other coastal lagoons of South-western Nigeria 
$\mathrm{W}=\mathrm{aLb}$ Where $\mathrm{W}=$ Weight of Pink shrimp in grams $(\mathrm{g}) \mathrm{L}$ $=$ Length of Pink Shrimp in centimetres $(\mathrm{cm}) \mathrm{a}=$ Regression constant $b=$ Regression coefficient Conversion of the above equation into a linear relationship using logarithmic transformation gives $\log \mathrm{W}=\log \mathrm{a}+\mathrm{b} \log \mathrm{L}$ (Pauly, 1983; Parsons, 1988)

\section{Condition Factor (K)}

The condition factor $(\mathrm{K})$ determines the effects of seasonal and habitat difference in the robustness and general well being of the species and the condition factor $(\mathrm{k})$ for the pink shrimps was calculated using the equation below:

$\mathrm{K}=\underline{100 \mathrm{~W}}$ (Gayanilo and Pauly, 1997)

$\mathrm{L}^{3} \quad$ Where: $\mathrm{L}=$ Length in centimetres $(\mathrm{cm}) ; \mathrm{W}=$ Weight in grams $(\mathrm{g}) ; \mathrm{K}=$ Condition factor.

\section{Statistical Analysis}

The Scatter diagrams were plotted to illustrate the relationship between the carapace length and the carapace weights of the shrimps. The log of carapace lengths and weights were obtained and plotted in order to establish the relationship between them.

\section{Results and Discussion}

The results of the Length-Weight Relationship (LWR) of 600 pink shrimps (Penaeus notialis) obtained from Lagos Lagoon are shown below. The carapace length of Penaeus notialis in this study ranged from $2.0 \mathrm{~cm}$ to $12.1 \mathrm{~cm}$ and $1.4 \mathrm{~cm}$ to $11.5 \mathrm{~cm}$ in females and males respectively, while the total length ranged from $3.9 \mathrm{~cm}$ to $19.9 \mathrm{~cm}$. The length-weight relationship was determined following a logarithmic transformation and the total number of samples (n), Regression constant (a), Regression coefficient (b) and Ranges ( $r$ ) of Length - weight Relationship of P. notialis are shown in Tables 1,2 and 3. The slope or regression coefficient (b) obtained for Carapace Length-Total Length Relationship ranged from 0.0001 in combined sexess to 1.3889 in males while the intercept (a) varied between 0.4754 and 0.8416. The value for ' $b$ ' and ' $a$ ' in Carapace Weight -Total Weight Relationship of P. notialis was highest in females and males, respectively. In the Carapace Length-Total Weight Relationship, the males' $P$. notialis showed the highest regression constant (a) and regression coefficient (b) of 1.2345 and 0.8059 , respectively. The ' $b$ ' values were calculated to find out whether the P. notialis was growing allometrically or isometrically and the values of the regression coefficient (b) and the slopes (a) for males, females and combined sexes were lower than 3.0, thus, reflecting a negative allometric growth for P. notialis. The regression lines derived from the data for the P. notialis showed a linear relationship between the two variables (length and weight).

Length-weight regressions have been used frequently to estimate weight from length because direct weight measurements can be time-consuming in the field (Chu et al., 1995; Sinovcic et al., 2004). The results obtained using a logarithmic transformation and the values of regression constant ' $a$ ', regression coefficient ' $b$ ' and ranges ' $r$ ' of length-weight relationship of Penaeus notialis showed a negative allometric growth and these are not in agreement with the results of Yakubu and Ansa (2007) in as they reported that both Penaeus notialis and Penaeus monodon showed positive allometric pattern of growth in Buguma Creek. This variation in the values of ' $a$ ', 'b' and ' $r$ ' could be attributed to the fact that length - weight relationship of a species varies according to locality and season (Medina-Reyha, 2001; Prasad, 2001).

The values obtained for the condition factor (K) of the 600 P. notialis (413 males and 187 females) from Lagos Lagoon in relation to sizes are shown in Table 4 . The results showed that there were differences in the condition factors for males and females. The lowest $\mathrm{K}$ values $(0.70)$ for the female species was found in size group 7.5-8.4 while the highest was obtained in size group 6.5-7.4. The male species had $\mathrm{K}$ values ranging between 0.18 and 80.29 . There was variation in condition values for the combined sexes as the size group 1.0 - 1.4 had the highest K-value and size group 6.5 - 7.4 had the lowest $\mathrm{K}$-value. The mean condition factor obtained from this study showed significant variations between sexes, thus, indicating sex dependent.

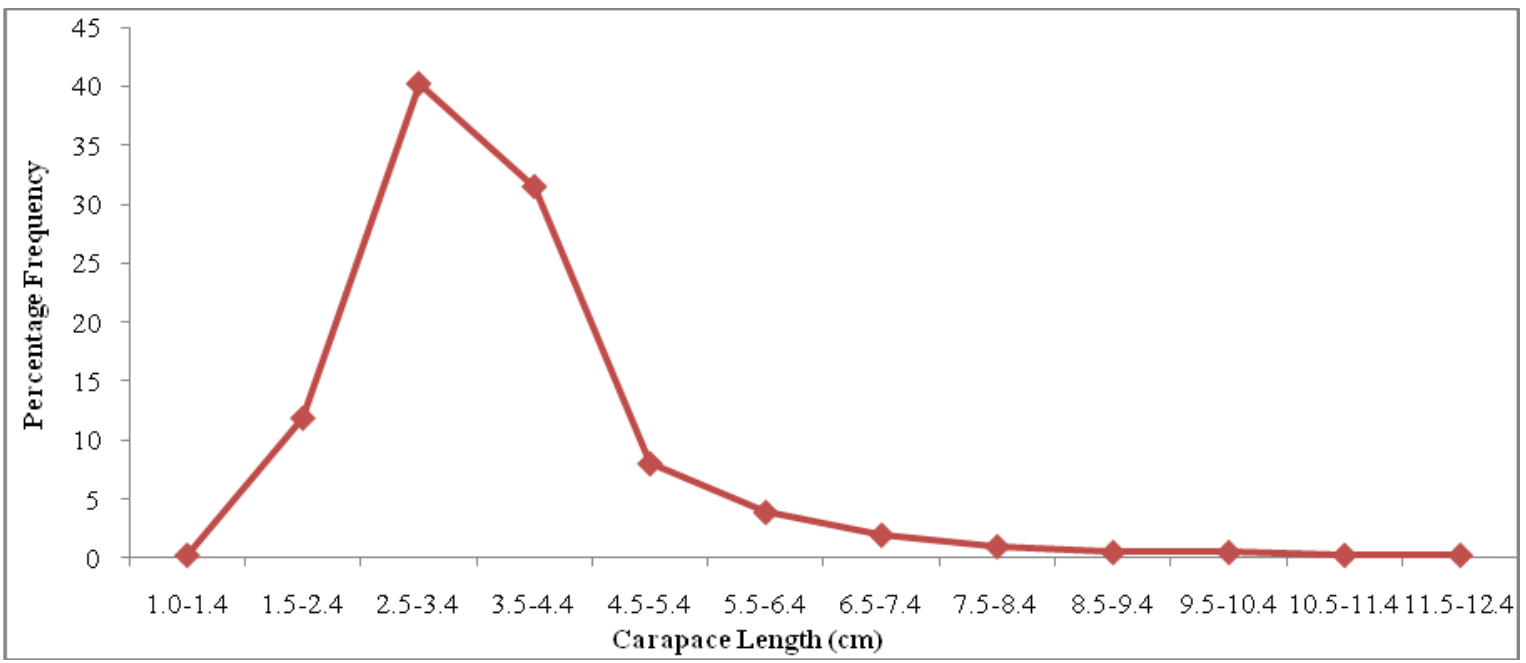

Figure 2. Carapace Length Frequency Distribution of P. notialis (Males) 


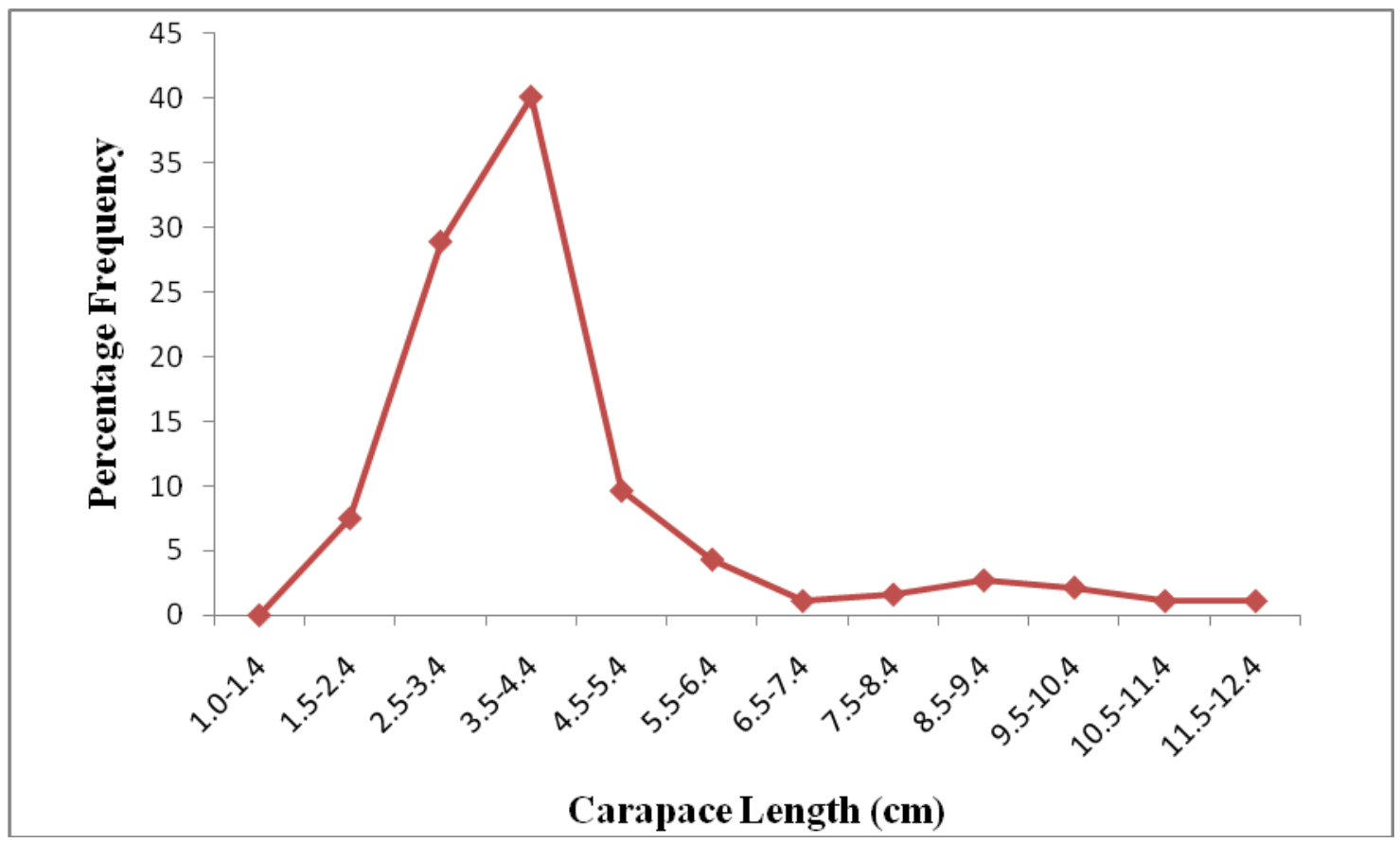

Figure 3. Carapace Length Frequency Distribution of P. notialis (Females)

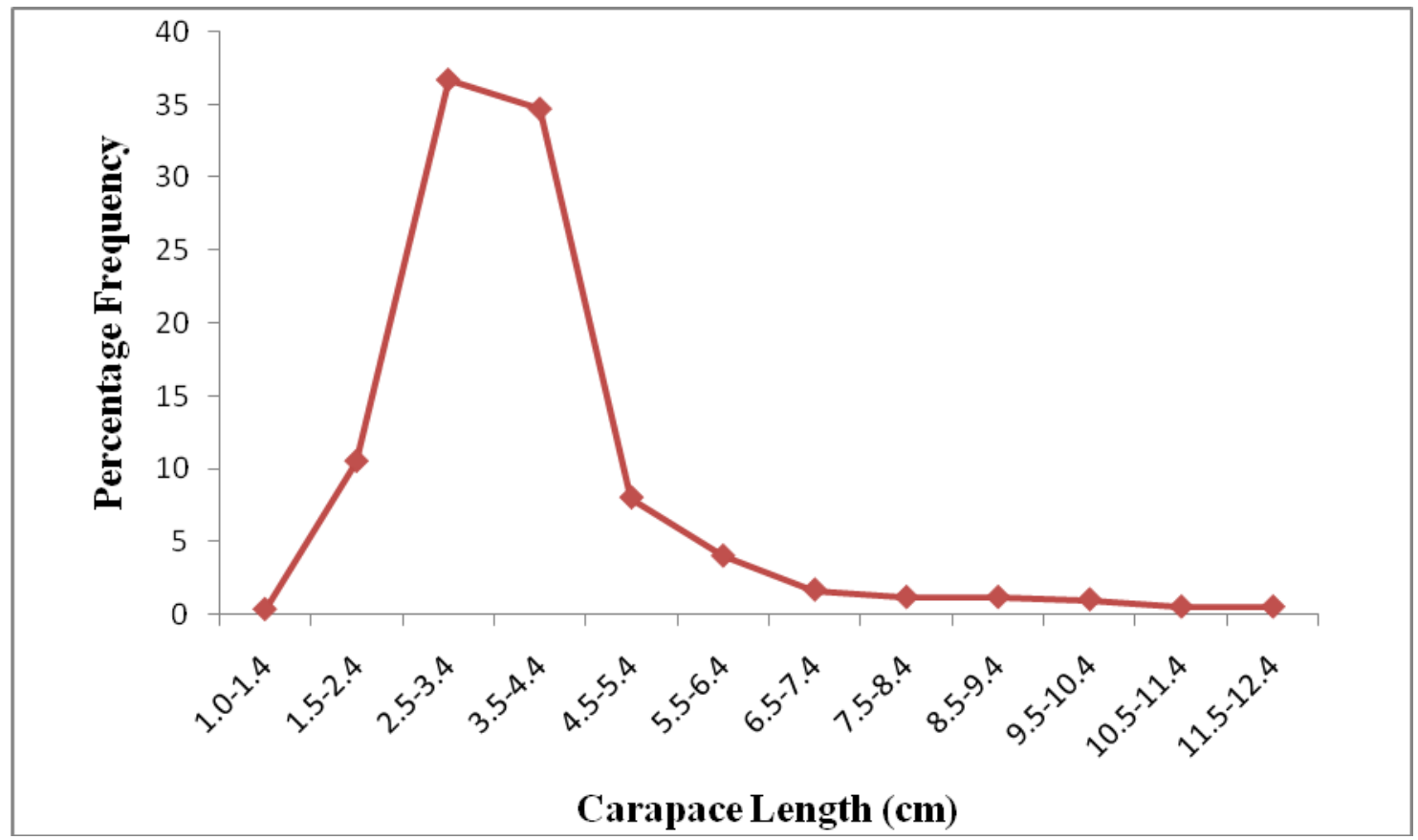

Figure 4. Carapace Length Frequency Distribution of P. notialis (Combined Sexes)

Table 1. The total number of samples (n), Regression constant (a), Regression coefficient (b) and Ranges (r) of Carapace Length-Total Length Relationship of P. notialis

\begin{tabular}{|c|c|c|c|c|c|c|c|}
\hline Sex & Year & $\mathrm{n}$ & $\mathrm{a}$ & $\mathrm{b}$ & $\mathrm{r}$ & $\mathrm{r}^{2}$ & $\mathrm{~W}=\mathrm{aL}^{\mathrm{b}}$ \\
\hline Male & 2009 & 413 & 0.4754 & 1.3889 & 0.0360 & 0.0013 & $0.4754 \mathrm{~L} 1.3889$ \\
\hline Female & 2009 & 187 & 0.6439 & 0.5617 & 0.5808 & 0.3374 & $0.6439 \mathrm{~L} 0.5617$ \\
\hline Both Sexes & 2009 & 600 & 0.8416 & 0.0001 & 0.0387 & 0.0015 & $0.8416 \mathrm{~L} 0.0001$ \\
\hline
\end{tabular}

Table 2. The total number of samples (n), Regression constant (a), Regression coefficient (b) and Ranges (r) of Carapace Weight -Total Weight Relationship of $\mathrm{P}$. notialis

\begin{tabular}{|c|c|c|c|c|c|c|c|}
\hline Sex & Year & $\mathrm{n}$ & $\mathrm{a}$ & $\mathrm{b}$ & $\mathrm{r}$ & $\mathrm{r}^{2}$ & $\mathrm{~W}=\mathrm{aL}^{\mathrm{b}}$ \\
\hline Male & 2009 & 413 & 0.5388 & 0.6199 & 0.5495 & 0.3020 & $0.5388 \mathrm{~L} 0.6199$ \\
\hline Female & 2009 & 187 & 0.3974 & 0.8171 & 0.6275 & 0.3938 & $0.3974 \mathrm{~L} 0.8171$ \\
\hline Both Sexes & 2009 & 600 & 0.0299 & 0.4919 & 0.5800 & 0.3365 & $0.0299 \mathrm{~L} 0.4919$ \\
\hline
\end{tabular}


Table 3. The total number of samples (n), Regression constant (a), Regression coefficient (b) and Ranges (r) of Carapace Length-Total Weight Relationship of P. notialis

\begin{tabular}{|c|c|c|c|c|c|c|c|}
\hline Sex & Year & $\mathrm{n}$ & $\mathrm{a}$ & $\mathrm{b}$ & $\mathrm{r}$ & $\mathrm{r}^{2}$ & $\mathrm{~W}=\mathrm{aL}^{\mathrm{b}}$ \\
\hline Male & 2009 & 413 & 1.2345 & 0.8059 & 0.3535 & 0.1250 & $1.2345 \mathrm{~L} 0.8059$ \\
\hline Female & 2009 & 187 & 1.1063 & 0.6877 & 0.307 & 0.1201 & $1.1063 \mathrm{~L} 0.6877$ \\
\hline Both Sexes & 2009 & 600 & 0.4243 & 0.0121 & 0.354 & 0.4045 & $0.4243 \mathrm{~L} 0.0121$ \\
\hline
\end{tabular}

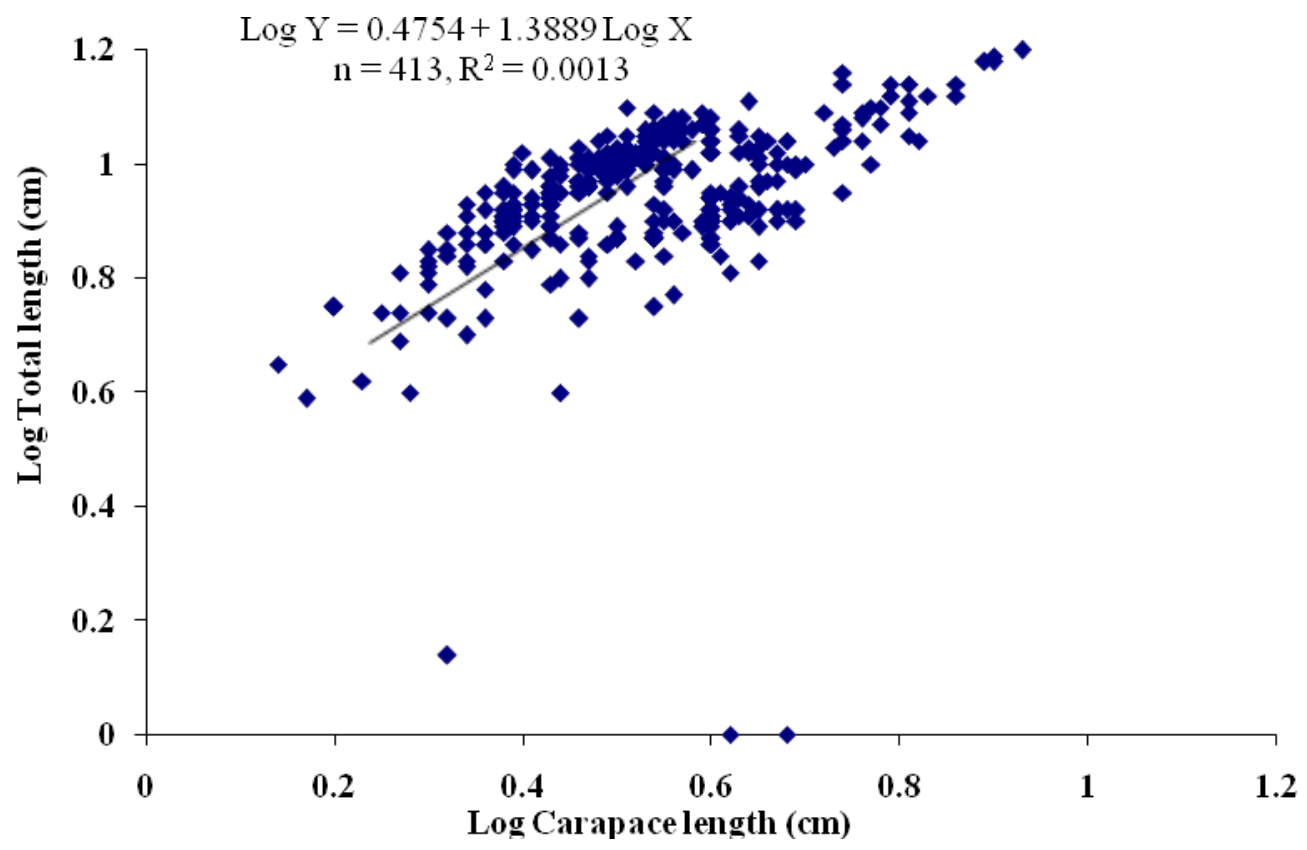

Figure 5. Log Carapace Length - Log Total Length of P. notialis (males) off Lagos Lagoon from January - June,2009

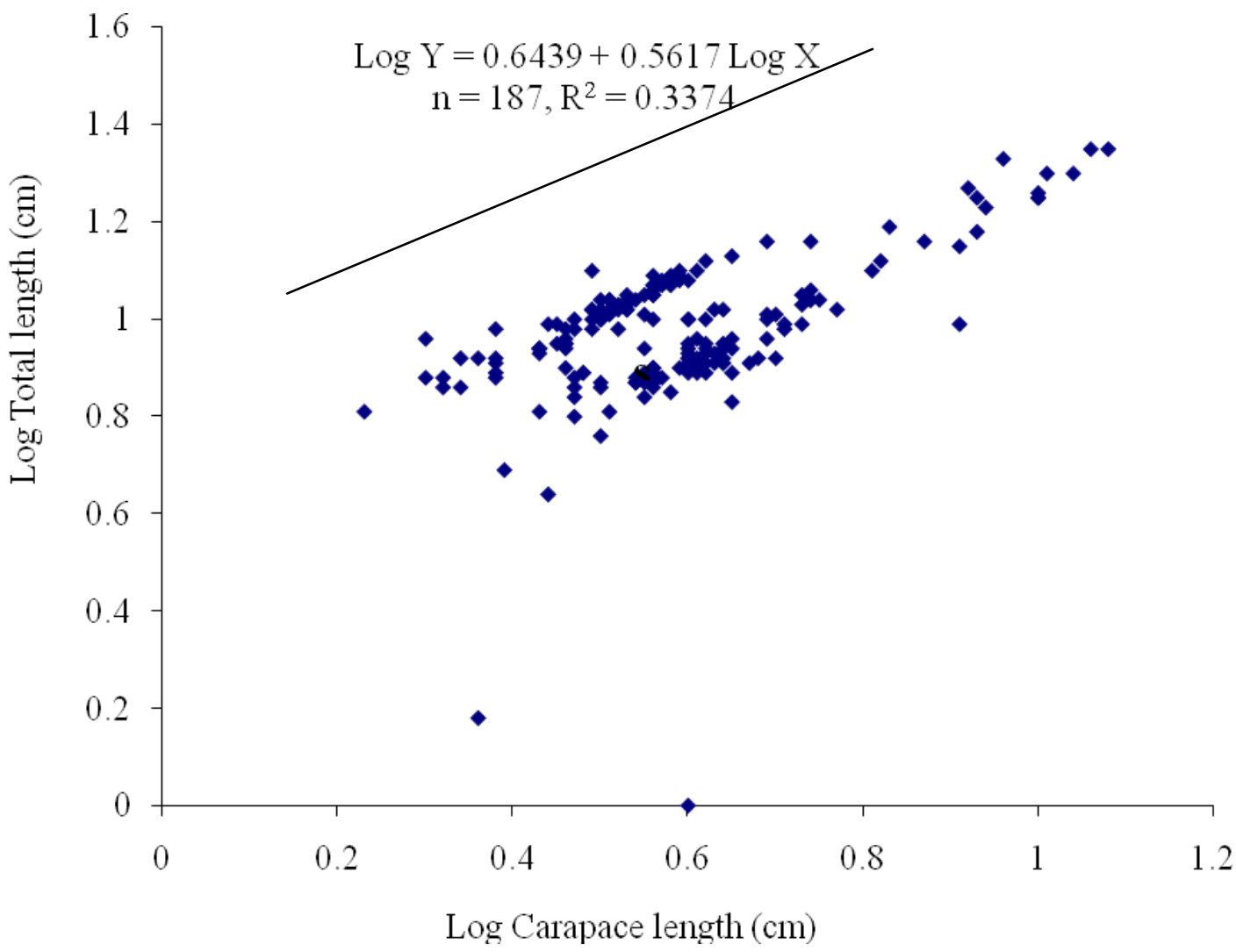

Figure 6. Log Carapace Length - Log Total Length of P. notialis (females) off Lagos Lagoon from January - June, 2009 


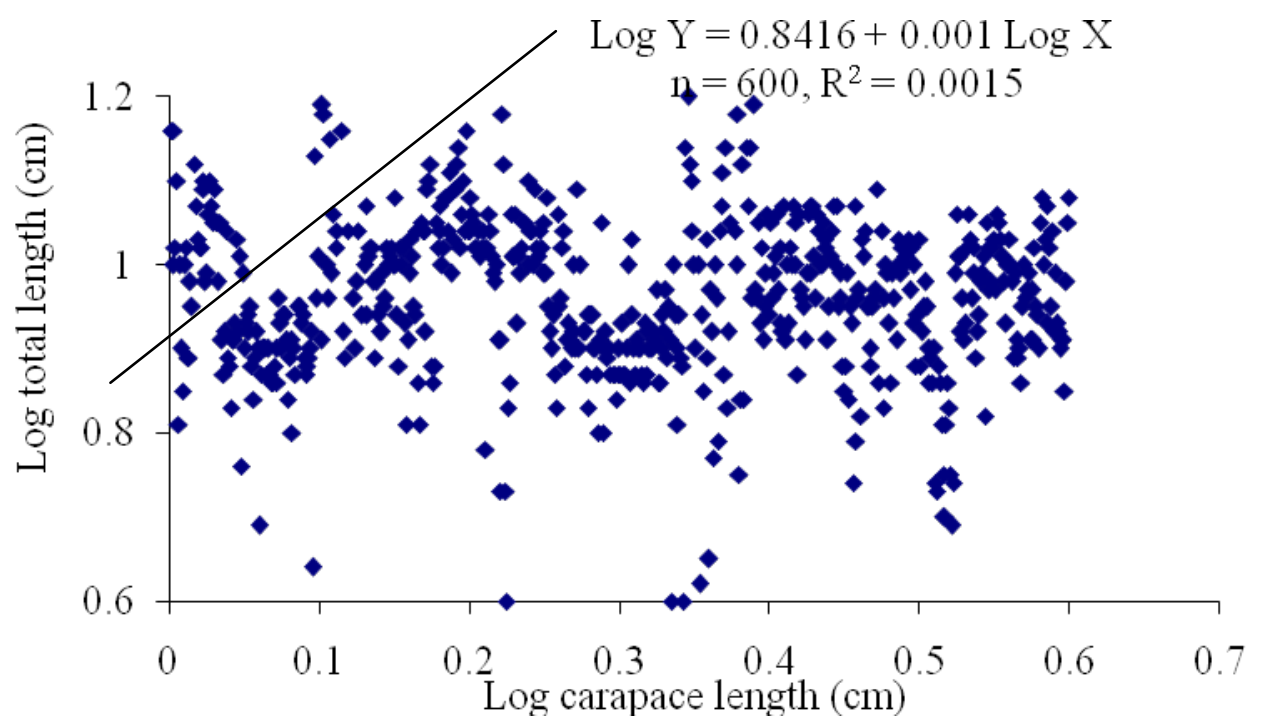

Figure 7. Log Carapace Length - Log Total Length relationship of P. notialis (combined sexes) off Lagos Lagoon from January - June, 2009

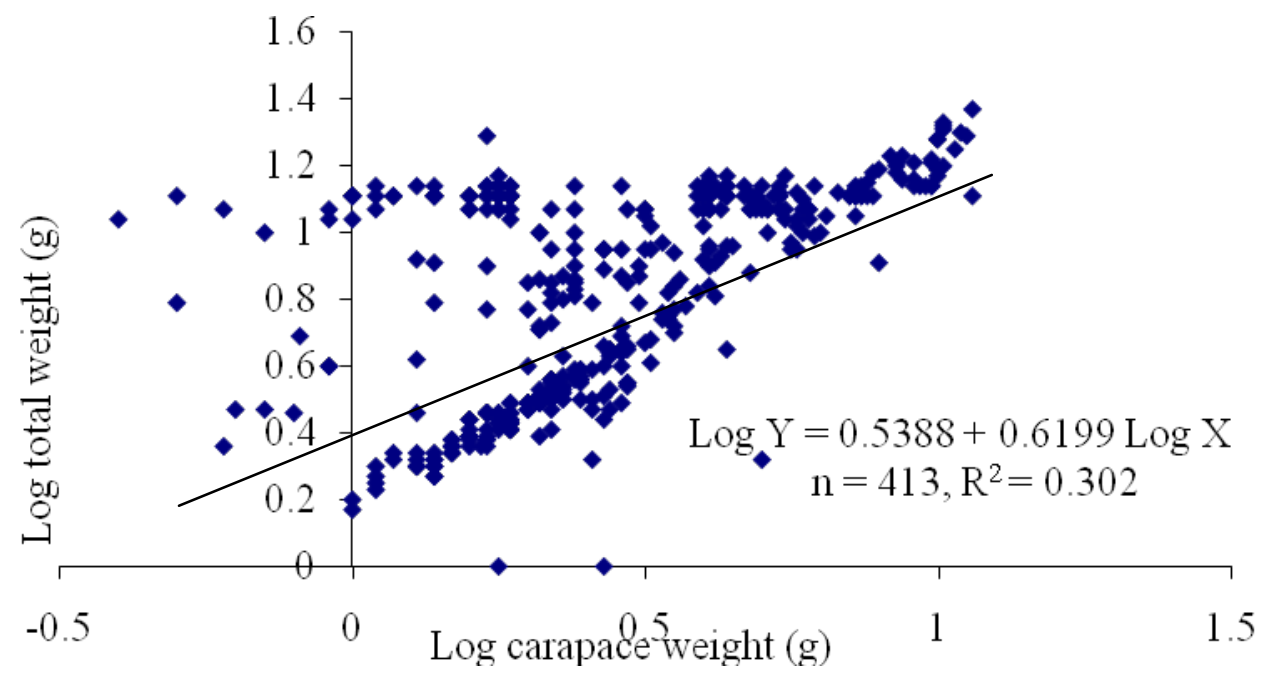

Figure 8. Log Carapace Weight - Log Total Weight of P. notialis (Males) off Lagos Lagoon from January - June, 2009.

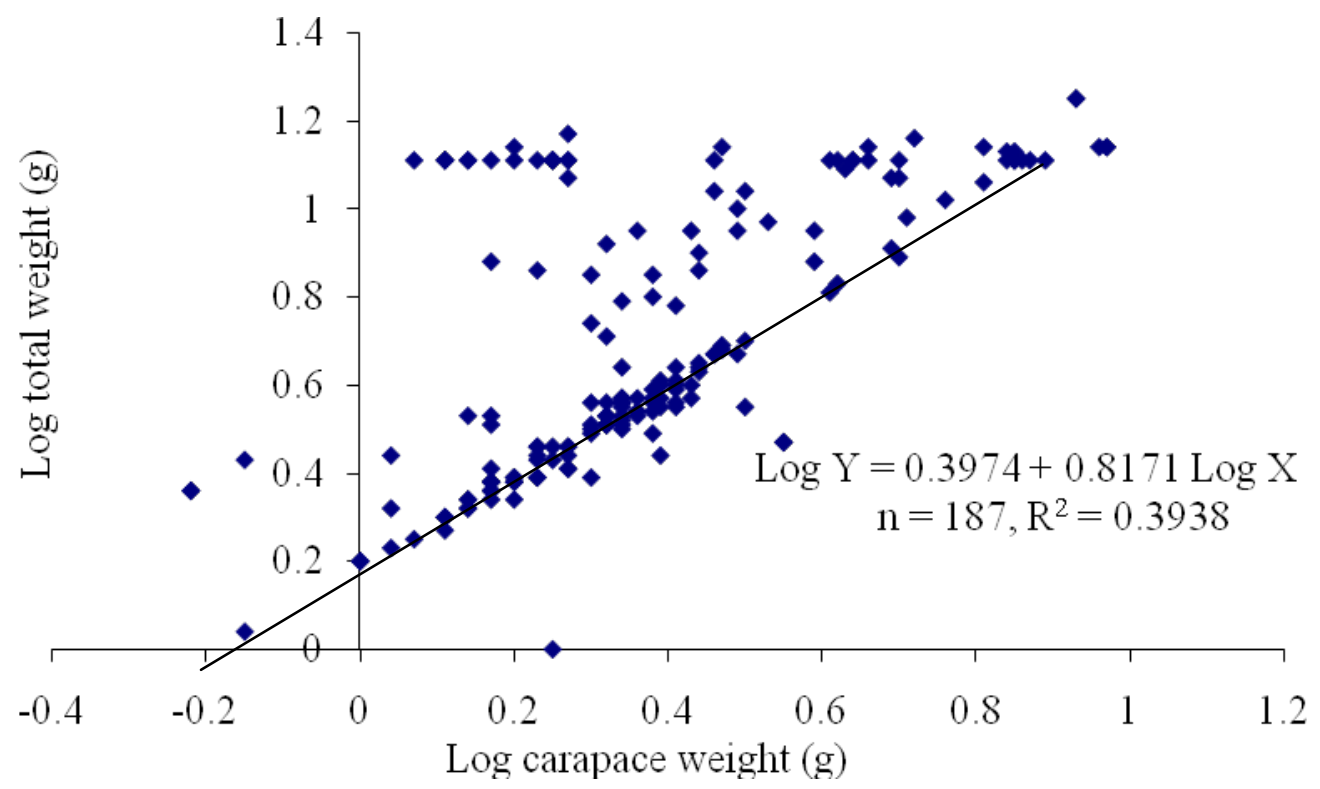

Figure 9. Log Carapace Weight - Log Total Weight of P. notialis (Females) off Lagos Lagoon from January - June,2009 


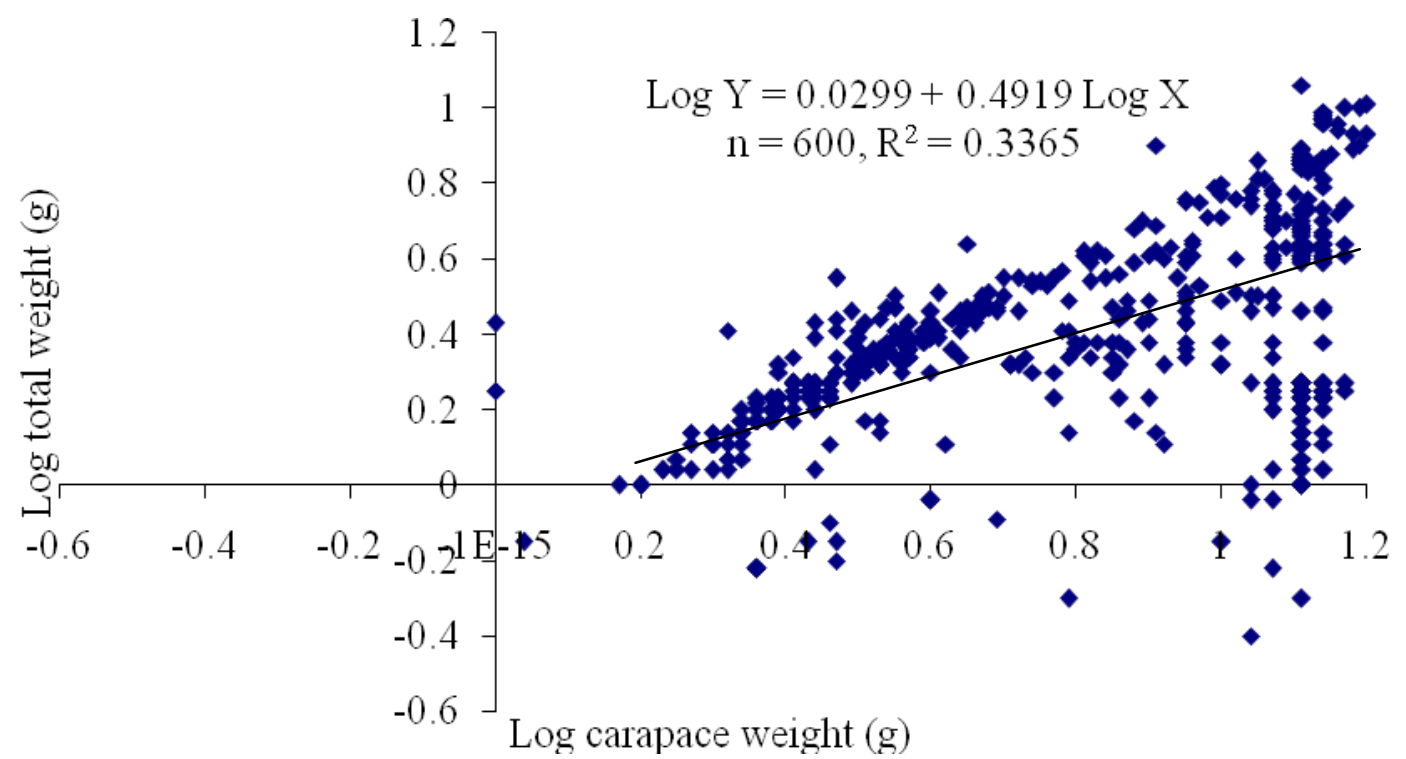

Figure 10. Log Carapace Weight - Log Total Weight relationship of P. notialis (Combined sexes) off Lagos Lagoon from January - June, 2009

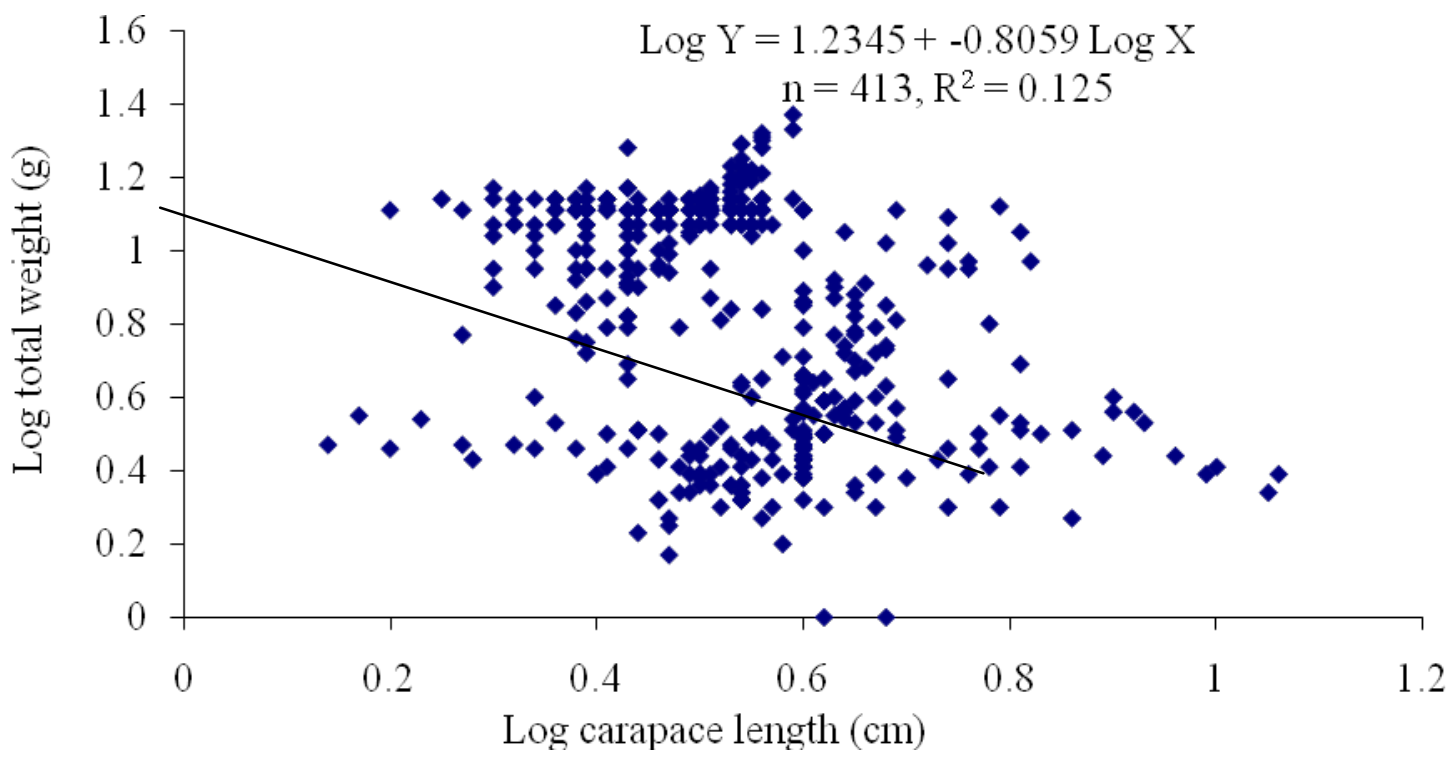

Figure 11. Log Carapace Length - Log Total Weight of P. notialis (Males) off Lagos Lagoon from January - June, 2009

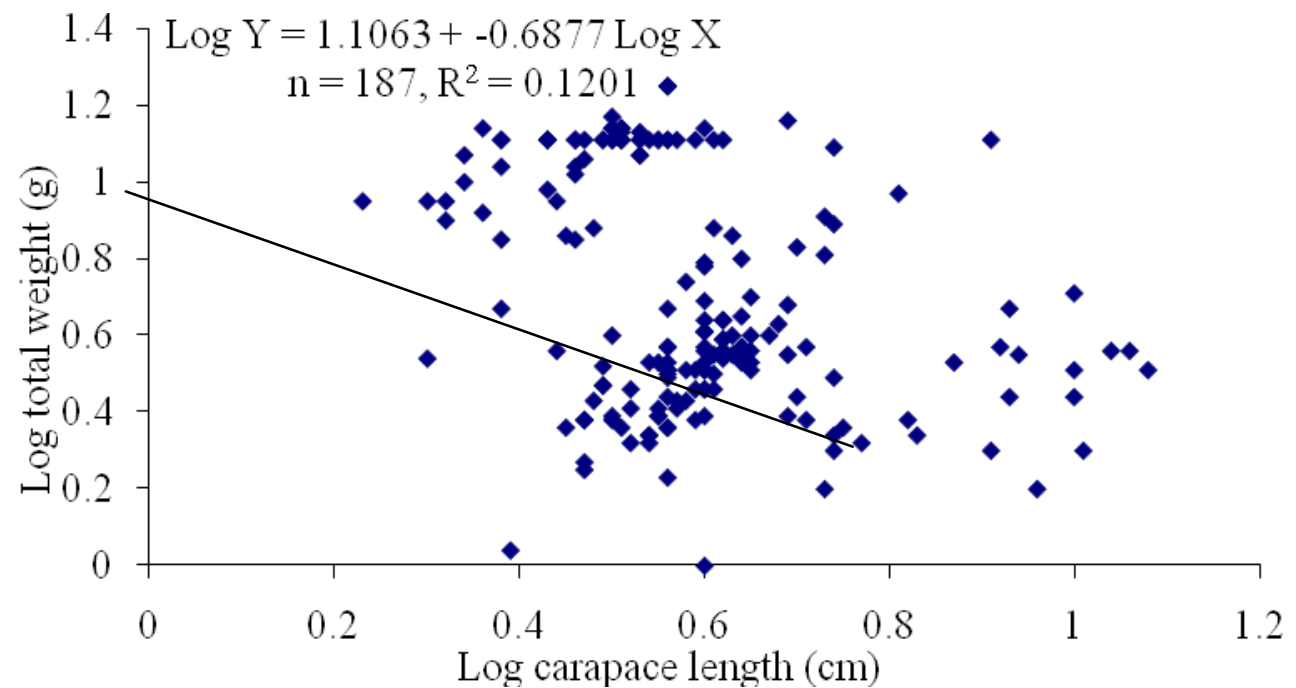

Figure 12. Log Carapace Length - Log Total Weight of P. notialis (Females) off Lagos Lagoon from January - June, 2009. 


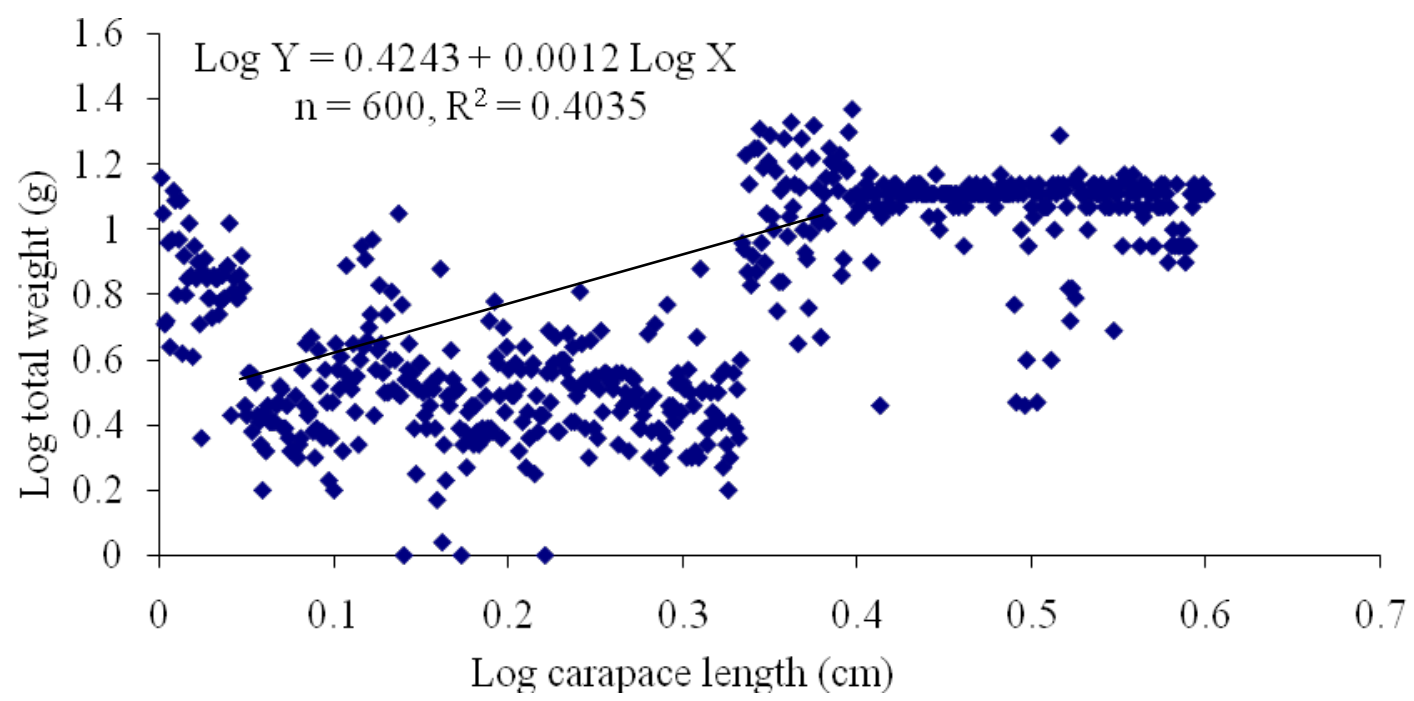

Figure13. Log Carapace Length - Log Total Weight of P. notialis (Combined sexes) off Lagos Lagoon from January - June, 2009

Table 4. Condition factor (K) for P. notialis off Lagos Lagoon from January - June, 2009

\begin{tabular}{|c|c|c|c|c|c|c|c|c|c|c|c|c|}
\hline \multirow{2}{*}{$\begin{array}{l}\text { Size Group } \\
\text { (cm) }\end{array}$} & \multicolumn{4}{|c|}{ Male } & \multicolumn{4}{|c|}{ Female } & \multicolumn{4}{|c|}{ Both Sexes (Combined) } \\
\hline & $\mathrm{N}$ & $\mathrm{CL}$ & $\mathrm{CW}$ & $\mathrm{K}$ & $\mathrm{N}$ & $\mathrm{CL}$ & $\mathrm{CW}$ & $\mathrm{K}$ & $\mathrm{N}$ & $\mathrm{CL}$ & $\mathrm{CW}$ & $\mathrm{K}$ \\
\hline $1.0-1.4$ & 1 & 1.4 & 2.2 & 80.29 & 0 & 0 & 0 & 0 & 1 & 1.4 & 2.2 & 80.29 \\
\hline $1.5-2.4$ & 49 & 2.2 & 2.8 & 26.29 & 14 & 2 & 3.2 & 4.0 & 63 & 2.1 & 3 & 32.40 \\
\hline $2.5-3.4$ & 166 & 3 & 3.6 & 13.33 & 54 & 3.1 & 3.3 & 1.07 & 220 & 3.1 & 3.5 & 11.75 \\
\hline $3.5-4.4$ & 130 & 3.9 & 3.6 & 6.07 & 75 & 3.9 & 2.5 & 4.21 & 208 & 3.9 & 3.1 & 5.23 \\
\hline $4.5-5.4$ & 33 & 4.7 & 2.6 & 2.50 & 18 & 4.9 & 2.8 & 2.38 & 48 & 4.4 & 2.7 & 3.17 \\
\hline $5.5-6.4$ & 16 & 5.8 & 2.8 & 1.44 & 8 & 5.7 & 2.6 & 1.40 & 24 & 5.8 & 2.7 & 1.38 \\
\hline $6.5-7.4$ & 8 & 6.7 & 3.2 & 1.06 & 2 & 6.7 & 1.6 & 5.32 & 10 & 6.7 & 2.4 & 0.80 \\
\hline $7.5-8.4$ & 4 & 8.1 & 2.1 & 3.95 & 3 & 8 & 3.6 & 0.70 & 7 & 8.1 & 2.9 & 1.55 \\
\hline $8.5-9.4$ & 2 & 9 & 2.8 & 3.84 & 5 & 8.7 & 2.3 & 3.49 & 7 & 8.9 & 2.6 & 2.37 \\
\hline $9.5-10.4$ & 2 & 10 & 1.8 & 0.18 & 4 & 10.1 & 1.9 & 1.84 & 6 & 10.1 & 1.9 & 1.18 \\
\hline $10.5-11.4$ & 1 & 11.3 & 1.5 & 4.42 & 2 & 10.7 & 1.7 & 1.39 & 3 & 11 & 1.6 & 2.12 \\
\hline $11.5-12.4$ & 1 & 11.5 & 2.1 & 1.38 & 2 & 11.8 & 2.2 & 1.34 & 3 & 11.7 & 2.2 & 1.14 \\
\hline Total & 413 & & & & 187 & & & & 600 & & & \\
\hline
\end{tabular}

Keys: N: Number of Occurrence; CL: Carapace length (cm); CW: Carapace weight (g); K: Condition Factor

\section{3: $83-93$}

\section{REFERENCES}

[1] Adetayo, J.A. and Kusemiju, K. (1994). Some aspects of the biology of pink shrimp, Penaeus notialis in the Lagos Lagoon, Nigeria. Journal of Science Research and Development. 1(1): 80-84

[2] Amos, W.H. and Amos. S. H. (1997). National Audubon Society Nature Guides: Atlantic and Gulf Coasts. Alfred A. Knopf, Inc., New York, NY. 121pp

[3] Ansa, E.J. (2005). Studies of the benthic macrofauna of the Andoni flats in the Niger Delta Area of Nigeria. Ph.D Thesis University of Port Harcourt, Port Harcourt, Nigeria, pp: 242

[4] Carvajal, R. and Nebot, A. (1998). Growth model for white shrimp in semi-intensive farming using inductive reasoning methodology. Computers and Electronics in Agriculture 19:187-210

[5] Chu, K.H., Chen, Q.C., Huang, L.M. and Wong, C.K (1995). Morphometric analysis of commercially important penaeid shrimps from the Zhejiang estuary, China. Fisheries Research,
[6] Dall, W., Hill, B.J., Rothlisberg, P.C. and Staples, D.J. (1990). Biology of the Penaeidae. In: Blaxter, J.H.S., Southward, A.J. (Eds.), Advances in Marine Biology, vol. 27. Academic Press, London, UK. 489 pp

[7] Fagade, S.O. (1979). Observations on the biology of species of Tilapia from Lagos Lagoon. Bull. De.1' F.A.N., 41(A3): 60-72

[8] Gayanilo, F.C. and. Pauly, D. (1997). FAO-ICLARM Stock Assessment Tools (FiSAT). FAO Computerised Information Series (fisheries) No. 8, Rome, pp: 262

[9] Griffith, D.R.W. and Wigglesworth, J.M. (1993). Growth rhythms in the shrimp Penaeus vannamei and P. schmitti. Marine Biology 115:295-299

[10] Jalihal, D.R., Sankolli, N. and Shenoy, S. (1993).Evolution of Larval development patterns and the process of fresh waterization in the prawn genus Macrobrachium Bate.1868 (Decapoda, Palaemonidae. Crustaceana 65:365-376

[11] Kusemiju, K. (1975). The bionomics and distribution of the pink shrimp, Penaeus duorarum (Burkenroad) off Lagos coast, Nigeria. Bullde I' I.F.A.N. A. 37(4): 775-783 
[12] Lawal - Are, A. O. (2006). The biology and culture potentials of the blue crab, Callinectes amnicola (De rocheburne) from Badagry, Lagos and Lekki Lagoons, Nigeria. Ph.D Thesis $300 \mathrm{pp}$

[13] Lawal-Are, A.O and Nwankwo, H. (2011). Biology of the Hairy Mangrove Crab, Sersema Huzardii (Decapoda: Graspidae) from a Tropical Estuarine Lagoon. Journal of American Science ; 7(7):402-408

[14] Lawal -Are, A. O., Onyema, I. C. and Akande, T. R. (2010). The Water Chemistry, Crustacean Zooplankton and Some Faunal Species of a Tropical Tidal Creeks in Lagos, Nigeria. Journal of American Science, 6(1):81 -90

[15] Lemos, D., Phan, V.N. and Alvarez, G. (2001). Growth, oxygen consumption, ammonia- excretion, biochemical composition and energy content of Farfantepenaeus paulensis Pérez- Farfante (Crustacean, Decapoda, and Penaeidae) early post- larvae in different salinities. Journal of Experimental Marine Biology and Ecology, 261: 55-74

[16] Lopez-Martinez, J., Arreguín-Sánchez, F., Hernandez Vazquez, S., García-Juárez, A.R. and Valenzuela-Quiñonez, W. (2003). Inter-annual variation of growth of the brown shrimp Farfantepenaeus californiensis and its relation to temperature. Fisheries Research, 61:95-105

[17] Medina-Reyha, C.E. (2001). Growth and emigration of white shrimp, Litopenaeus vennamei in the Mar Muerto Lagoon, Southern Mexico. NAGA, ICLARM Q., 24(1-2): 30-34

[18] Mendes, B., Fonseca, P. and Campos, A. (2004). Weight length relationships for 46 fish species of the Portuguese west coast. J. of Applied Icht., 20: 355- 361

[19] Miao, S. and Tu, S. (1996). Modelling the effect of thermic amplitude on growing Chinese shrimp, Penaeus chinensis (Osbeck). Ecological Modelling 88: 93-100

[20] Parsons, R. (1988). Statistical Analysis: A Decision making Approach. ( $2^{\text {nd }}$ Edition), Harper and Row Publishers, New York, $791 \mathrm{pp}$

[21] Pauly, D. (1983). Some simple methods for the assessment of tropical fish stocks. FAO Fish. Tech. Pap., 234: 52p
[22] Prasad, G., (2001). Length - weight relationship of Penaeus monodon reared in semi-intensive culture systems of Kerala, India. NAGA, ICLARM Q., 24(1-2): 16-17

[23] Sanchez, A.J. (1997). Habitat preference of Penaeus duorarum (Burkenroad) (Crustacea: Decapoda) in a tropical coastal lagoon, southwest Gulf of Mexico. Journ. Exp. Mar. Biol. and Ecol. 217:107-117

[24] Sinovcic, G., Franicevic, M., Zorica, B. and Ciles-Kec, V. (2004). Length-weight and length-length relationships for 10 pelagic fish species from the Adriatic Sea (Croatia). J. of Applied Ichthyology, 20: 156-158

[25] Solarin, B.B. (1998). The hydrobiology, fishes and fisheries of the Lagos Lagoon, Nigeria. Ph.D Thesis, University of Lagos, pp 235.

[26] Soyinka, O. O. (2008). The feeding ecology of Mugil cephalus (Linnaeus) from a high brackish tropical lagoon in South-west, Nigeria. African Journal of Biotechnology 7 (22).4192-4198

[27] Ugwumba, A. O. and Kusemiju, K. (1992). Aspect of the reproductive biology of the ten pounder Elops lacerta (Vals) from the Lekki Lagoon, Lagos Lagoon and off the Lagos Coast, Nigeria. Nig. J. Sci. 26: $305-315$

[28] Welcome, R.L. (1979). Fisheries Ecology of Flood Plain Rivers . Longman Press, London, pp: 317

[29] Wyban, J., Walsh, W.A. and Godwin, D.M. (1995). Temperature effects on growth, feeding rate and feed conversion of the pacific white shrimp (Penaeus vannamei). Aquaculture 138: $267-279$

[30] Yakubu, A.S. and Ansa, E. F. (2007). Length-weight relationships of the pink shrimp Penaeus monodon and giant tiger shrimp P. monodon of Buguma Creek in the Niger Delta Nigeria. The Zool., 5: 47-53

[31] Ye, Y., Bishop, J.M., Fetta, N., Abdulqader, E., Al- Mohammadi, J., Alsaffar, A.H. and Almatar, S. (2003). Spatial variation in growth of the green tiger prawn (Penaeus semisulcatus) along the coastal waters of Kuwait, eastern Saudi Arabia, Bahrain, and Qatar. Ices Journal of Marine Science 60:806-817 